\title{
Sistem Pengolahan arsip di kantor kecamatan ILIR TIMUR III PALEMBANG
}

\section{Muhammad Bu'ang, Reni Anggraini, Samha Meristin, Sari Puspita \\ Setiawati, Ummi Kalsuma Mareta}

\begin{abstract}
Archive management is an important aspect in an organization, both business and government organizations. Increasing the volume of work of an organization, causes an increase in the number of records produced. The increasing number of archives over time, requires good handling so that the information contained in the archive can be found quickly and precisely. Archiving is a very important part of office work. Archiving is needed in the implementation of office activities because the archive is the memory center for every activity in the office. However, in handling the archives at the Palembang City Government Office, Ilir Timur Tiga District is still inefficient because it still implements conventional information systems and takes a lot of time for information retrieval. This study aims to determine the management of existing records in the office of Ilir Timur sub-district. Data collection uses observation and interview techniques. The results of this study are that management of records management has not been completely transferred to media into electronic archives. It is hoped that in the future it can be completely transferred from the manual archive to an electronic archive. It is expected that staff in the special archives section at the office of Ilir Timur Subdistrict in Palembang to be able to manage records effectively and efficiently by using electronic media in archiving management will obtain the benefits of speed, convenience and accuracy of invoices.
\end{abstract}

Keywords: Archive, Archive Management.

\section{Pendahuluan}

\section{A. Latar Belakang}

Berdasarkan Undang-undang No.7 Tahun 1971 tentang ketentuan-ketentuan pokok kearsipan pasal 1 mengemukakan bahwa 
arsip itu adalah naskah-naskah yang dibuat dan di terima oleh badanbadan swasta dan perorangan, dalam bentuk corak apapun baik dalam keadaan tunggal maupun berkelompok, dalam rangka pelaksanaan kehidupan kebangsaan (Basuki, 2015).

Menurut Patricia E. Wallace, Jo Ann Lee dan Dexter R. Schumbert, Ahli kearsipan dari belahan benua Eropa, dalam buku Records Management : Integrateg Information System (1992) telah membuat satu definisi tentang file elektronik. Electronic file generally consist of any collection of information.that is recorded in a code that can be stored by computer and stored on some medium for retrieval viewing and use. Apabila diterjemahkan, file elektronik pada umumnya terbagi dalam beberapa kumpulan informasi yang direkam dalam kode yang dapat disimpan pada komputer dan dalam beberapa media untuk dilihat kembali dan dipergunakan, file elektronik pada umumnya terbagi dalam beberapa kumpulan informasi yang direkam dalam kode yang dapat disimpan pada komputer dan dalam beberapa media untuk dilihat kembali dan dipergunakan.

Kemudian Dokumen Elektronik adalah setiap informasi elektronik yang dibuat, diteruskan, dikirimkan, diterima, atau disimpan dalam bentuk analog, digital, elektromagnetik, optikal, atau sejenisnya, yang dapat dilihat, ditampilkan, dan/atau didengar melalui komputer atau sistem elektronik, termasuk tetapi tidak terbatas pada tulisan, suara, gambar, peta, rancangan, foto, elektronik data interchange (EDI), surat elektronik (electronic mail), telegram, teleks, telecopy atau sejenisnya, huruf, tanda, angka, kode akses, simbol atau perforasi yang telah diolah yang memiliki arti atau dapat dipahami oleh orang yang mampu memahami (Bauer, 2000). 
Dalam upaya mewujudkan penyelenggaraan negara yang baik dan bersih serta dalam menjaga agar dinamika gerak maju masyarakat, bangsa, dan negara pada pilar perjuangan mencapai cita-cita nasional, arsip yang tercipta harus dapat menjadi sumber informasi, acuan dan bahan pembelajaran masyarakat, bangsa dan negara. Oleh karena itu, setiap lembaga negara, pemerintah daerah, lembaga pendidikan, organisasi politik, organisasi kemasyarakatan, perusahaan dan perorangan harus menunjukkan tanggung jawabnya dalam penyelenggaraan, penciptaan, pengelolaan, dan pelaporan arsip yang tercipta dari kegiatan-kegiatannya.pengelolaan arsip bertujuan pokok untuk menjamin ketersediaan arsip sebagai bahan akuntabilitas kinerja dan sebagai alat bukti yang sah dalam rangka pelaksanaan fungsi dan tugas lembaga (Hermawan \& Ulum, 2017).

Organisasi sector public maupun privat, dalam kegiatan administrasi akan selalu berkaitan dengan arsip. Arsip yang penting dan yang dibutuhkan bagi jalannya organisasi. Dengan semakin meningkatnya aktivitas dan dinamika organisasi maka akan membawa kecenderungan bertambahnya kebutuhan akan informasi dalam mendukung proses pengambilan keputusan untuk mencapai tujuan.

Menurut Bhartos, 2013. Mengemukakan bahwa Peranan arsip yang penting dalam kegiatan organisasi sebagai pusat ingatan, sumber informasi dan sebagai media pengawasan, yang diperlukan dalam kegiatan proses penrencanaan, proses analisa, pengembangan, perumusan kebijakan, pengambilan keputusan, pembuatan laporan, pertanggung jawaban,penilaian dan pengendalian setepat-tepatnya (Rosalin, 2017). 
Mengingat pentingnya peranan arsip dalam pengambilan keputusan dan sebagai bukti akuntabilitas, maka arsip yang tersimpan dalam organisasi haruslah dikelola dengan baik karena merupakan sumber informasi dari organisasi yang bersangkutan dengan menyampaikan informasi yang tepat dan sesuai dengan kebutuhan tanpa perlu adanya kesimpangsiuran maupun kebingungan dalam memproses informasi tersebut. Oleh karena itu di butuhkan manajemen arsip yang mudah dan cepat, baik di kelola secara konvensional maupun elektronik (Amsyah, 1995).

\section{B. Rumusan Masalah}

1. Bagaimana Sistem Pengelolaan arsip di Kantor Kecamatan Ilir Timur III Palembang?

2. Bagaimana Pemeliharaan arsip yang ada di Kantor Kecamatan Ilir Timur III Palembang?

3. Bagaimana penyusutan arsip di Kantor Ilir Timur III Palembang?

4. Apa saja kendala-kendala yang dihadapi oleh pengelolan arsip di Kantor Kecamatan Ilir Timur III Palembang?

\section{Tujuan}

1. Mengetahui bagaimana sistem pengelolaan arsip di Kantor Kecamatan Ilir Timur 111 Palembang

2. Mengetahui bagaimana pemeliharaan arsip di Kantor Kecamatan Ilir Timur III

3. Untuk mengetahui bagaimana system penyusutan arsip yang ada di Kantor Kecamatan Ilir Timur III Palembang

4. Mengetahui kendala-kendala apa saja yang di hadapi dalam pengelolaan arsip di Kantor Kecamatan Ilir Tinur III Palembang

\section{Metode Penelitian}


Jenis penelitian yang digunakan dalam penelitian ini adalah deskriptif kualitatif. Penelitian deskriptif kualitatif adalah penelitian yang dilakukan berdasarkan pada fakta yang ada atau fenomena yang secara empiris hidup pada penutur-penuturnya sehingga dapat di paparkan apa adanya (Sudaryanto, 1993). Tujuan dari penelitian deskriptif kualitatif adalah untuk mendeskripsikan data yang diperolaeh dari informan secara jelas. Beberapa jenis penelitian kualitatif yang selama ini sering digunakan antara lain, interview, observasi, penelitian etnografi, studi kasus, studi ilmiah, penelitian historical (Sri Hartinah, 2014).

Makalah ini menggunakan jenis penelitian termasuk jenis penelitian deskriptif yang menggunakan pendekatan kualitatif. Pendekatan kualitatif merupakan suatu proses penelitian dan pemahaman yang berdasarkan pada metodologi yang menyelidiki suatu fenomena sosial dan masalah manusia, di dalam prosedur penelitian kualitatif menghasilkan data deskriptif berupa kata-kata tertulis maupun lisan dari perilaku dan orang yang diamati.

Pemilihan pendekatan kualitatif disebabkan karena sifat dari masalah yang diteliti adalah mendeskripsikan masalah atau fenomena yang terjadi. Selain itu pendekatan ini sesuai dengan yang diinginkan peneliti untuk mendapatkan wawasan tentang sesuatu yang baru dan sedikit diketahui, karena pendekatan kualitatif dapat memberikan rincian yang kompleks tentang fenomena yang sulit diungkapkan oleh pendekatan kuantitatif. Subjek dari penelitian ini adalah Pengelolaan Arsip di Kantor Kecamatan Ilir Timur 111 palembang Sumatera Selatan. Dalam penelitian ini yang menjadi objek penelitian adalah Kantor Kecamatan Ilir Timur 111 Palembang, Sumatera Selatan. pengelolaan arsip yang terletak di Jalan Jl. MP. Mangkunegara No.20 di Kota 
Palembang Sumatera Selatan. Penelitian ini dilaksanakan Pada Tanggal 8-16 Oktober 2018.

Teknik pengumpulan data yang digunakan penulis adalah wawancara, observasi, serta studi dokumentasi. Teknik analisis data yang digunakan dalam penelitian ini adalah teknik analisis domain. Teknik analisis domain digunakan untuk menganalisis gambaran objek penelitian secara umum, namun relatif utuh tentang objek penelitian tersebut. Hingga pada akhirnya diperoleh suatu deskripsi yang jelas tentang pengelolaan arsip di Kantor Kecamatan Ilir Timur 111 Sumatera Selatan.

\section{Pembahasan}

A. Pengelolaan Arsip di Kantor Kecamatan Ilir Timur III

\section{Palembang}

Istilah kearsipan berasal dari kata “arsip”. Dalam bahasa yunani arsip berasal dari kata "archeon" yang memiliki arti sebuah kantor. Kata arsip bermula dari banyaknya dokumen yang di ciptakan oleh pemerintah .secara sederhana arsip memiiki arti recod, rekam, rekaman, catatan atau berkas yang di ciptakan oleh sebuah organisasi baik organisasi public maupun privat. Menurut kamus lengkap bahasa Indonesia , arti arsip adalah dokumen yang di simpan sebagai refrensi, dokumen berupa surat atau akta dan sebagainya yang di keluarkan oleh instansi resmi.Istilah arsip menurut barthos (2013) adalah suatu catatan yang tertulis baik dalam bentuk gambar atau bagan yang memuat keterangan -keterangan mengenai subyek (pokok persoalan) (Basuki, 2005).

Keberadaan arsip bukanlah hal yang diciptakan secara khusus, tetapi arsip tercipta secara otomatis sebagai bukti pelaksanaan kegiatan administrasi atau transaksi. Arsip mempunyai nilai yang 
sangat penting dalam berbagai hal, selain sebagai informasi, arsip juga merupakan bahan bukti yang dapat di pertanggung jawabkan kebenarannya.

Arsip merupakan suatu kegiatan yang sangat penting selama suatu organisasi yang masih melaksanakan kegiatannya, baik dalam kegiatan rutin maupun dalam hal pengembangan kegiatan yang dilakukan. Public records arrive at an archival institution during the inactive stage of the records lifecycle. Hal ini dapat diartikan sebagai catatan dalam arsip dinamis merupakan hal yang penting dalam suatu lembaga baik pemerintah maupun swasta karena merupakan kesinambungan rutinitas dari dari lembaga publik tersebut.

Dalam suatu kearsipan harus adanya Pengelolaan yang baik agar jika saat di butuhkan mudah untuk di temukan kembali, menurut malabay dalam konteks manajemen berasal dari kata manage yang dimaksud adalah mengelola (Basuki, 2003). Pengelolaan arsip adalah kegiatan menerima, mencatat dan menyimpan arsip tersebut.tujuan dari pengelolaan arsip adalah untuk menjamin ketersediaan arsip dalam penyelenggaraan kegiatan sebagai bahan akutanbilitas kinerja dan alat bukti yang sah berdasarkan suatu system memenuhi persyaratan: Sistematis, utuh, menyeluruh dan sesuai dengan standar, prosedur dan criteria (Merliana, 2013).

Pengelolaan arsip di Kantor Kecamatan Ilir Timur III Palembang yang disana arsip dikelola dengan cukup baik. Kantor Kecamatan Ilir Timur III Palembang ini baru berdiri. Memiliki banyak arsip yang bersifat dinamis dan pengelolaan arsipnya masih tergolong manual. Arsip yang ada di Kantor Kecamatan Ilir Timur III Palembang. Arsip yang diperoleh di Kantor Kecamatan Ilir Timur III Palembang berbeda- 
beda tergantung dari bagian-bagiannya seperti Pelayanan Umum, Arsip yang diperoleh yaitu Arsip pengajuan kartu keluarga (KK), KTP Sementara. KTP, Dan Arsip SIUP (Surat Izin Usaha Perusahaan). Bagian kepegawaian Mengelola Surat Masuk, Data Kepegawaian dan Surat Serah Terima.Sedangkan bagian dari Trantip juga mempunyai Arsipnya sendiri seperti SKBD, SKBC Dan Surat Menyurat lainnya. Setiap Bidang mengelola Arsipnya masing-masing. Pegawai yang ada di Kantor Kecamatan Ilir Timur III Palembang memiliki 150 pegawai PNS Dan NonPSD. Pegawai yang khusus mengelola arsip bagian kepegawaian ada tiga orang yaitu, awaludin,S Kom , Retno Ayu KartikaPutri,SKM ,Dan Anisha.

Proses pengelolaan arsip yang ada di Kantor Kecamatab Ilir Timur III Palembang adalah sebagai berikut:

\section{Penciptaan arsip}

Pada tahap ini merupakan aktivitas awal dari arsip yaitu dari awal arsip itu datang, menurut hasil penelitian yang sudah di lakukan di Kantor Kecamatan Ilir Timur III Palembang yaitu menurut pegawai bagian khusus arsip di Badan Kepegawaian Awaludin S, Kom, Surat yang masuk seperti contohnya surat observasi, surat tersebut di terima oleh bagian kepegawaian kemudian surat diajukan ke Kasubag dan lanjut ke Camat.

2. Pencatatan surat

Setelah surat di agendakan, surat masuk dilampirkan dan dicatat dalam buku agenda. Surat dicatat pada peredaran naskah, atau dicatat pada sebuah buku yang terdiri dari kolom-kolom yang berisi nomor urut, nomor agenda, tanggal masuk,isi surat, dan kepada pihak mana surat itu dikembalikan.

3. Penyimpanan surat 
Surat yang telah dicatat dalam buku agenda kemudian di simpan, di Kantor Kecamatan Ilir Timur III Palembang ini penyimpanannya menggunakan cara penyimpanan berdasarkan subyek, contohnya seperti surat masuk, surat keluar.

\section{B. Penemuan Kembali Arsip}

Penemuan kembali adalah cara bagaimana suatu dokumen atau arsip dapat dengan mudah ditemukan dalam waktu yang cepat dan tepat (Jumiati, 2011). Penemuan kembali dokumen atau arsip bukan hanya sekedar menemukan berkas-berkas dari tampat penyimpanannya akan tetapi,yang lebih penting adalah informasi yang terkandung dalam dokumen itu dapat di temukan guna pengambilan keputusan dalam suatu masalah (Hendrawan \& Ulum, 2017). yang dimaksud dengan penemuan kembali arsip merupakan kegiatan memastikan dimana warkat atau arsip yang akan di pergunakan disimpan dalam kelompok berkas apa disusun menurut system apa dan bagaimana cara mengembalikannya (Wursanto, 2007).

Berdasarkan sistem yang ada di Kecamatan Ilir Timur III, sistem temu kembali arsip berdasarkan subjek atau bentuk arsip yang tersedia(diagram,manual,laporan penelitian), mekanisme kerja (SOP) penelusuran dalam temu kembali. dan di simpang dibagian lemari khusus menyimpan dokumen yang ada di Kecamatan Ilir Timur III Pengelola arsip tinggal melihat pada buku agenda arsip apa yang ingin dicari apakah ada dalam daftar atau tidak,setelah itu langsung menuju lemari tempat penyimpanan arsip, dan mencari arsip berdasarkan subjek yang dicari. Dalam proses penemuan kembali arsip ini hanya dapat dilakukan oleh staf pada bagian kepegawaian karena data-data yang ada di kecamatan Ilir Timur III bersifat sangat rahasia karena menyangkut pada data-data banyak orang di satu kecamatan tersebut. 


\section{Pemeliharaan Arsip}

Pemeliharaan adalah usaha penjagaan arsip agar kondisi fisiknya tidak rusak selama masih mempunyai nilai guna.menurut suparji,dkk (2004:30) menyatakan bahwa penyebab kerusakan arsip ada dua yaitu (Amsyah, 2017) :

1. Faktor intrinsic Yaitu penyebab kerusakan arsip yang berasal dari arsip itu sendiri seperti kualitas kertas,pengaruh tinta pengaruh lim perekat dan sebagainya.

2. Faktor ekstrinsik

Yaitu penyebab kerusakan yang berawal dari luar benda arsip yakni lingkungan fisik organism perusak dan kelalaian manusia.

Pemeliharaan arsip dapat di lakukan dengan cara sebagai berikut (Mulyono, 1985) :

1. Pengaturan ruangan

2. Pemeliharaan tempat penyimpanan

3. Penggunaan bahan -bahan pencengah

4. Peraturan yang tidak boleh di langar

5. Kebersihan

Perawatan untuk arsip-arsip yang ada di kecamatan Ilir Timur III Palembang, Menurut hasil observasi dilapangan sistem manajemen arsip sudah memenuhi standar tetapi untuk dari segi pengelolaan arsip-arsip yang ada di kecamatan Ilir Timur III Palembang masih perlu diperbaiki seperti prosedur yang akan digunakan dalam melakukan temu kembali arsip-arsip. walaupun kecamatan Ilir Timur III Palembang ini tergolong baru tetapi arsip-asrip sudah banyak menumpuk, karena terlalu banyaknya arsip-arsip di kecamatan Ilir Timur III Jadi banyaknya arsip-arsip dibiarkan saja menumpuk tanpa adanya tindakan dari pihak staf kepegawaian khususnya staf 
kearsipan. Sehingga mengakibatkan sering terjadinya kehilangan suatu dokumen-dokumen tersebut.

\section{Penyusutan Arsip}

Arsip yang disimpan oleh suatu lembaga memiliki nilai guna yang jangka waktunya berbeda-beda. Ada arsip yang memiliki kegunaan abadi serta ada yang dimiliki kegunaan jangka waktu tertentu (Rosalin, 2017). Sebagian besar arsip yang disimpan oleh lembaga memiliki nilai kegunaan yang jangka waktunya terbatas,oleh karena itu arsip semacam itu suatu ketika harus disusut.Durotul Yatimaha(2009:212) menyatakan bahwa:

1. Mendayagunakan arsip sebagai berkas kerja maupun sebagai referensi

2. menghemat ruangan, peralatan dan perlengkapan

3. mempercepat penemuan kembali arsip

4. menyelamatkan bahan bukti pertanggungjawaban.

Menurut barthos ada beberapa cara dalam penyusutan arsip diantaranya yaitu:

1. memindahkan arsip inaktif dari unit pengola ke unit kearsipan dalam lingkungan lembaga-lembaga negara atau badan-badan pemerintahan masing-masing

2. memusnahkan arsip sesuai dengan ketentuan-ketentuan yang berlaku

3. menyerahkan arsip statis oleh unit kearsipan kepada arsip nasional.

Penyusutan arsip yang ada di kantor Kecamatan Ilir Timur III Palembang belum pernah dilakukan penyusutan. Karena di kantor Pemerintah Kota Palembang Kecamatan Ilir Timur Tiga palembang baru berdiri sekitar satu tahun lebih membuat penyusutan arsip masih belum dilaksanakan.

\section{E. Kendala-Kendala Dalam Pengelolaan Arsip}


Dalam pengelolaan arsip terdapat hambatan atau kendala yang dihadapi dalam mengelola arsip. Hambatan-hambatan tersebut terjadi karena adanya masalah yang timbul berupa pelaksanaan pengelolaan arsip dinamis yang belum maksimal, keterbatasan kendala untuk pengadaan fasilitas pengelolaan arsip, belum adanya tenaga arsiparis, petugas arsip yang belum dapat diklat tentang arsip, latar belakang pendidikan pegawai kearsipan, dan lingkungan kerja yang belum memadai (Juliani \& Suliyati, 2013). hal ini perlu mendapat solusi yang tepat agar pengelolaan arsipnya lebih baik yaitu dengan memberikan diklat dan pengadaan fasilitas.sistem pengelolaan arsip terdapat 2 sistem yaitu secara manual dan elektronik, masing-masing system tersebut memiliki kendala-kendala tersendiri (Basuki, 2003) diantaranya:

1. Konvensional ( manual)

a. Jumlah arsip selalu bertambah

b. Tempat penyimpanan terbatas ,butuh ruangan penyimpanan yng luas

c. Pencarian kembali dokumen yang rumit,inefisiensi kerja

d. Kertas mudah rusak

e. Pendistribusian dokumen antar pegawai kurang efektif

2. Digital (elektronik)
a. Sangat tergantung pada hubungan listrik
b. Sdm harus mengoperasikan komputer
c. Rentan terhadap virus.

Adapun kendala yang ada di Kantor Kecamatan Ilir Timur III Palembang ini diantaranya seperti:

1. Staf kepegawaiannya bukan orang yang ahli bidang kearsipan, jadi pada saat observasi mereka hanya menjelaskan secara umumnya saja tidak secara mendetail karena ketebatasan pengetahuan yang mereka miliki. 
2. Khusus data kepegawaian sudah di alih mediakan ke elektronik tetapi arsip-arsip yang lain yang ada di kecamatan Ilir Timur III Palembamg untuk saat ini belum bisa di alih mediakan dari manual ke elektronik dikarena kecamatan Ilir Timur III Palembang ini dibawah naungan pemerintahan jadi jika ingin mengalih mediakan dari manual ke elektronik belum bisa karena harus ada intruksi dari pemerintah jika ada intruksi untuk mengalih mediakan dari manual ke elektronik baru bisa mengalih mediakan.

3. Dari segi fasilitas yang ada di kantor kecamatan Ilir Timur III Palembang ini fasilitasnya belum memadai untuk menyimpan Arsip-arsip tersebut karena kurangnya lemari-lemari khusus arsip-arsip tersebut.

\section{F. Upaya Menangani Kendala Pengelolaan Arsip Dinamis}

Upaya yang dilakukan dalam menangani kendala pengelolaan arsip dinamis adalah:

1. Fasilitas

b. Perlu adanya ruangan khusus yang digunakan sebagai ruang kearsipan sehingga terpisah dari ruangan yang lain.

c. Perlu dilakukan penambahan fasilitas kearsipan sehingga kegiatan kearsipan khususnya arsip dinamis aktif dapat berjalan lebih lancar.

2. Sumber Daya Manusia

a. Untuk memperlancar pengelolaan arsip dinamis aktif, perlu adanya suatu pembelajaran khusus mengenai kearsipan yang ditujukan pada pegawai pengelola kearsipan.

b. Perlu adanya penambahan pegawai yang memenuhi syarat sebagai seorang arsiparis. untuk dapat menjadi petugas 
kearsipan yang baik diperlukan sekurangkurangnya empat syarat, yaitu ketelitian, kecerdasan, kecekatan, dan kerapian (Fajri \& Syahyuman, 2018).

\section{Penutup}

\section{A. Kesimpulan}

Berdasarkan uraian dan pembahasan diatas, maka dapat diambil kesimpulan sebagai berikut:

1. Sistem pengelolaan arsip di kantor Pemerintah Kota Palembang Kecamatan Ilir Timur Tiga masih menggunakan sistem manual. menggunakan sistem manual dikarenakan dalam pengelolahaan arsip dalam bentuk digital belum memenuhi izin dari lembaga yang menaungi nya karena Pemerintah Kota Palembang Kecamatan Ilir Timur Tiga adalah lembaga dibawah naungan lembaga pemerintah provinsi yang dimana tidak boleh sembarangan dalam melakukan proses pengelolaan arsip dan sifa.tnya rahasia karena menyangkut data pribadi

2. Untuk pemeliharaan arsip aktif dan inaktif adalah dengan cara pengamanan dan pengelolaan.Cara pemeliharaan arsip belum sesuai dengan prosedur pengelolaan arsip. Karena arsiparis yang ada di kantor Pemerintah Kota Palembang Kecamatan Ilir Timur Tiga, tidak ada riwayat pendidikan arsip sehingga pemeliharaan arsip belum sesuai dengan prosedur pemeliharaan.

3. belum ada penyusutan arsip di kantor Pemerintah Kota Palembang Kecamatan Ilir Timur Tiga. Karena di kantor Pemerintah Kota Palembang Kecamatan Ilir Timur Tiga masih tergolong baru dan arsip di di kantor Pemerintah Kota 
Palembang Kecamatan Ilir Timur Tiga mengenai data pribadi seseorang seperti ktp, kartu keluarga, dll.

4. Kendala-kendala yang dihadapi oleh pengelolaan arsip di kantor Pemerintah Kota Palembang Kecamatan Ilir Timur Tiga adalah kurang sarana dan prasarananya yang ada pada unit pengelola arsip kantor pemerintah kota Palembang kecamatan ilir timur tiga dan arsiparis yang tidak ada sama sekali riwayat pendidikan sehingga pengelolaannya tidak sesuai dengan teknik dan prosedur pengelolaan arsip.

\section{B. Saran}

Berdasarkan kesimpulan yang dikemukakan diatas, maka ada beberapa hal yang kiranya dapat merupakan saran bagi kantor pemerintahan kota Palembang kecamatan ilir timur tiga yaitu:

a. Hendaknya arsiparis dapat diberikan tunjangan fungsional arsiparis untuk meningkatkan kesahjeteraannya sehingga menjalankan tugasnya dengan baik dan efisien

b. Hendaknya kepala dinas/kantor/satuan kerja agar benarbenar sepenuhnya yang bertanggung jawab atas pengamanan dan pengelolaan kearsipan dilingkungan kearsipan. Sehingga apa bila timbul permasalahan yang menyakut mengenai pembuktian suatu perkara tindak pidana terhadap pelaksanaan kegiatan. Arsip dari kegiatan masyarakat tersebut dapat menjadi bukti pertanggung jawaban atas kebijakan diambilnya

c. Hendaknya setiap tahun diadakan diklat kearsipan guna mencetak tenaga kearsipan yang terdidik dan terampil , sehingga menimbulkan minat pegawai negeri sipil untuk bekerja pada bidang kearsipan. 


\section{Daftar Pustaka}

Adlan Ali, Tanzili.2006.Pedoman Lengkap Menulis Surat.Jakarta: Kawan Pustaka.

Amsyah, Zulfli. 1995.Manajemen Kearsipan.Jakarta : Gramedia Pustaka Utama.

Basuki, Sulistyo.2003. Manajemen Arsip Dinamis:Pengantar Memahami dan mengelola informasi dan dokumen. Jakarta:Gramedia Pustaka Utama.

Basuki, Sulistyo. 2015.Pengantar Ilmu Kearsipan.Jakarta: Universitas Terbuka.

Bauer, M.W. 2000. “ Classical content analysis: a review “, in bauer , M.W. and Gaskell, G.(Eds), qualitative researching with text, image, and sound, sage, London, pp131-151.

Bhatos, Basir. 2007. Manajemen Kearsipan. Jakarta: Bumi Aksara.

Hamdani Fajri dan Syahyuman, "Sistem Pengelolaan Arsip Dinamis di Kantor Perpustakaan, Arsip, dan Dokumentasi," E-JOURNAL, Jurnal Ilmu Perpustakaan dan kearsipan, Program Studi Ilmu Informasi, Perpustakaan dan Kearsipan., Vol. 1, No. 1 (September 2012 Seri E), 416, dalam ejournal.unp.ac.id , Home , Vol 1, No 1 (2012), diakses tanggal 28 oktober 2018.

Juliani, Delisa dan Titiek suliyati. 2013. "Studi Komparatif Efektifitas Sistem Pengarsipan Manual Dengan Sistem Informasi Kearsipan Dinamis Di Badan Arsip Dan Perpustakaan Provinsi Jawa Tengah”.Jurnal Ilmu Perpustakaan, Vol.2,No.2. Online dari http://ejournal-s1.undip.ac.id/index.php/jip. diakses pada tanggal 28 Oktober 2018.

Jumiati, Emi. 2011. "Sarana dan Prasarana Kearsipan Di Pusat Teknologi Bahan Bakar Nuklir Batan”. Tanggerang:Puspiptek. No.7 diakses pada 20 Oktober 2018Kirhanta. 2014.Pengertian Arsip Vital.Tanggerang Selatan: Universitas Terbuka.

Mareta merliana. 2013. Pengelolaan Arsip Dinamis, Yogyakarta:FE.UNY

Muatiawatul, Wardah. 2016. Pengelolaan Arsip Dinamis.Jakarta:

Balai Pustaka

OC (Library of Congress). 2002. "Encoded Archival Description: Version 2002.” http://www.loc.gov/ead/.

NWDA (Northwest Digital Archives). 2012. "NWDA Best Practice Encoding Guidelines (NWDA BPG) for Encoded Archival Description (EAD)." Version 3.7. https://www.orbiscascade.org/file_viewer.php?id=551

Rosalin,Sovia. 2017.Manajemen Arsip Dinamis. Malang:UB Press 
Rosyidin Hendrawan,Muhammad. Mochamad Chazienul Ulum,2017.Pengantar Kearsipan: dan Isu Kebijakan ke Manajemen. Malang:UB Press

Sularso Mulyono. 1985.Dasar-dasar Kearsipan. Yogyakarta:Liberty Wursanto,ig. 2007. Kearsipan 2.Yogyakarta: Kanisius 